УДК 343.131

DOI https://doi.org/10.32849/2663-5313/2021.5.36

\title{
Олександра Бабаєва,
}

канд. юрид. наук, дочент

асистентка кафедри кримінального процесу та оперативно-розшукової діяльності

Начіонального юридичнго університету імені Ярослава Мудрого

\section{Олександра Іорданова,}

студентка міжнародно-правового факультету

Начіонального юридичного університету імені Ярослава Мудрого

\section{Кристина Лагутіна,}

студентка міжнародно-правового факультету

Начіонального юридичного університету імені Ярослава Мудрого

\section{ПРАВО НА НЕВТРУЧАННЯ У ПРИВАТНЕ ТА СІМЕЙНЕ ЖИТТЯ: ПРАКТИКА ЄВРОПЕЙСЬКОГО СУДУ 3 ПРАВ ЛЮДИНИ}

Стаття присвячена дослідженню права на невтручання у приватне та сімейне життя особи, яке закріплене у статті 8 Конвениї про захист прав людини і основоположних свобод 1950 року. Аналізу піддаються питання, пов'язані з історичним становленням поняття приватності, зокрема, згадується робота Платона «Держава», наукова стаття С. Уоррена та Л. Брандейса, якою було започатковано розвиток права людини на приватність, наукові статті вітчизняних учених, а також міжнародно-правові акти, в яких було офімійно закріплене дане поняття. Звертається увага на різні підходи до розгляду права на недоторканність приватного життя, приділяється увага аналізу чотирьох складових елементів права на невтручання у приватне та сімейне життя особи, а саме:приватне життя, сімейне життя, житло і кореспонденція. На основі наукових робіт фахівців у галузі права робиться акиент на тому, що до права на повагу приватного життя можна віднести інформачійний, фізичний, номінативний та просторовий складники.

На основі аналізу рішень Європейського суду з прав людини (далі - ССПл, Свропейський суд, Суд) було встановлено, що поняття «сімейне життя» охоплює зв'язки між иленами родини, причому підкреслено, що не існує різнии між оформленням і не оформленням спорідненості за законом, також було визначено поняття «житло» у розумінні Свропейського суду, розкрито складники терміна «приватного життя».

Зазначено, що до поняття «приватне життя» відносять такі аспекти, як фізична та психологічна чілісність особи, аспекти фізичної та сочіальної ідентичності особи, гендерна ідентифікаиія, ім'я, сексуальна орієнтаиія та статеве життя, систематичне спостереження і збір приватної інформації представниками влади, а також подальше збереження такої інформації у вигляді досьє.

Ретельну увагу приділено аналізу негативного і позитивного обов'язку держави у забезпеченні права на повагу до приватного та сімейного життя. Було підкреслено, що, визначаючи зобов'язання, необхідно брати до уваги справедливий баланс, який варто встановити між конкуруючими інтересами суспільства та окремого індивіда, приниип свободи розсуду держави як щодо законодавчих актів, так і шодо норм, які стосуються досягнення балансу конкуруючих публічних $і$ приватних інтересів, а також приниип необхідності застосування заходів щодо захисту прав, які охороняються статтею 8 Конвениї про захист прав людини і основоположних свобод 1950 року.

Ключові слова: приватність, ЄСПЛ, приватне життя, захист сімейного життя, Свропейський судз прав людини.

Постановка проблеми. Конституція України в ст. 32 проголошує, що ніхто не може зазнавати втручання в його особисте і сімейне життя, крім випадків, передбачених Конституцією України. Таким чином, на державу покладається обов'язок охорони відповідного права та контролю за його обмеженням в контексті не тільки Конститу- ційних вимог, а й міжнародних зобов'язань. Так, зокрема, право на невтручання у приватне та сімейне життя закріплено в ст. 8 Конвенції про захист прав людини і основоположних свобод. Складність забезпечення вказаного права особи зумовлена тим, що, 3 одного боку, приватне життя - це фундаментальне право особи, яке визнане у ряді 
міжнародних актів та сприймається як право на усамітнення та непублічний спосіб життя, з іншого - постає питання щодо законност його обмеження стосовно державних інтересів. Аналіз міжнародно-правових актів та практики Європейського суду з прав людини (далі - ЄСПЛ, Свропейський суд, Суд) дає можливість не тільки визначити багатоаспектність поняття приватного життя особи та межі втручання в нього взагалі та у кримінальному провадженні зокрема, а й застосовувати релевантні рішення Суду задля виключення порушення відповідного права особи, зокрема, у сфері кримінального судочинства.

Аналіз останніх досліджень і публікацій. Дослідженню різних аспектів проблематики забезпечення права особи на невтручання у приватне та сімейне життя присвячені роботи, зокрема, I. В. ВегериІжевської, О. В. Верхогляд-Герасименко, I. В. Гловюк, А. Замошкина, О. В. Капліної, В. П. Кацалова, С. Лихової, В. І. Мариніва, С. Т. Мішуровської, О. Пакевича, І. Л. Петрухіна, В. О. Серьогіна, Ю. І. Стецовського, Н. В. Устименка, С. Шевчука, О. Г. Шило та інших. Проте багатоаспектність права на невтручання у приватне і сімейне життя в умовах розвитку різних сфер діяльності людини та динамічна практика ЄСПЛ зумовлюють необхідність наукового осмислення та постійного аналізу з метою релевантного застосування правових позицій Суду.

Мета статті є аналіз історичних витоків права на приватність, визначення сутності та змісту складників права на невтручання у приватне і сімейне життя шляхом аналізу ст. 8 Конвенції та відповідної П практики ЄСПЛ.

Виклад основного матеріалу. Поняття «приватність» («privacy») є загальновживаним як у повсякденному житті, так й в правовій сфері, що підкреслює різноманітність проявів та втілень даного терміна. Увагу поняттю приватності приділяли у своїх роботах ще філософи та юристи Стародавнього світу. Античні мислителі розглядали термін «приватність» здебільшого 3 економічного боку, наприклад, у працях Платона містяться згадки про приватність щодо поділу землі в межах держави на дві частини: приватне і державне володіння [1, с. 115].

Одними з перших, хто здійснив детальний аналіз поняття «приватність» 3 точки зору права людини на усамітнення, залишення в спокої і непублічного життя, були випускники Гарвардської школи права С. Уоррен та Л. Брандейс [2, с. 152]. Так, у своїй науковій статті «Право на приват- ність» вони підкреслили важливість нерозповсюдження факту приватного життя шляхом наведення запитання: «Що підлягає захисту під час ситуації, коли людина згадує у листі до сина або у своєму щоденнику, що вона такого-то дня не обідала $з$ дружиною або чоловіком?» [2, с. 138]. У ході роздумів, які були доповнені аналізом рішень Верховного Суду Сполучених штатів Америки, автори доходять висновку, що захисту підлягає факт чи випадок із сімейного життя, а не авторське право на зміст листа чи щось інше [2, с. 140]. Стаття випускників Гарвардської школи права справила велике враження на юридичну спільноту, і згодом це призвело до законодавчого закріплення права на приватне життя.

Так, фундаментальним нормативноправовим актом, що закріпив право на приватне життя, стала Загальна декларація прав людини, яка була прийнята 10 грудня 1948 року Генеральною Асамблеєю Організації об'єднаних націй резолюцією 217 (III). У ст. 12 Загальної декларації було проголошено заборону безпідставного втручання в особисте і сімейне життя особи, безпідставного посягання на недоторканність його житла, тайну його кореспонденції або на його честь і репутацію. Більш того, законодавством повинні бути встановлені захисні механізми від такого втручання або таких посягань [3].

Міжнародний пакт про громадянські та політичні права 1966 року розширив сферу застосування права на приватне життя, закріпивши у ст. 7, 17 положення, що «жодна особа не може бути без її добровільної згоди піддана медичним чи науковим дослідам»; що «ніхто не може зазнавати безпідставного i незаконного втручання в його особисте та сімейне життя, свавільних чи незаконних посягань на недоторканість його житла, таємницю його кореспонденції чи незаконних посягань на його честь і репутацію»; що «кожна людина має право на захист закону від такого втручання або таких посягань» [4].

На європейському континенті загальним джерелом, яке закріплює та регулює право на приватне життя, є Конвенція про захист прав людини і основоположних свобод 1950 р. (далі - Конвенція), ст. 8 якої гарантує невід'ємність права на повагу до приватного і сімейного життя, житла та кореспонденції, а також окреслює випадки, за яких дозволяється обмеження цього права [5].

Як слушно зазначають деякі вітчизняні науковці, універсальні міжнародні договори відображують лише зміст права на приватне життя і не розкривають можливості та шляхи обмеження такого права [6, с. 14]. 
В. Серьогін запропонував розглядати право на недоторканність приватного життя, що закріплене у ст. 8 Конвенції, у трьох аспектах. По-перше, як право індивіда на власне життя, на дії щодо самого себе. Це право напряму пов'язане з індивідуальністю конкретної людини і забезпечує захист від втручання $з$ боку інших людей. По-друге, як неприпустимість втручання у приватне життя особи з боку держави, будь-яких організацій, установ, підприємств і фізичних осіб. По-третє, як право, що суміжне з такими правами, як право на недоторканність сімейного життя, право на недоторканність житла, право на недоторканність кореспонденції [7, с. 538]

О. Панкевич, проаналізувавши ст. 8 Конвенції з філологічного погляду, зробила висновок, що у зазначеній статті мається на увазі одне право з чотирма його різними аспектами, або, влучніше, складовими елементами [8, с. 51].

У свою чергу С. Шевчук на основі аналізу практики ЄСПЛ виокремлює чотири основні складники права на повагу приватного життя, а саме: інформаційний, що включає в себе поширення відомостей про особу, збір та обробку персональних даних; фізичний, що має на увазі захист фізичної недоторканності особи; комунікативний, що включає в себе безпеку та приватність листування, електронної пошти, телефонних розмов та інших видів приватних комунікацій; просторовий, який охоплює поняття дому, робочого місця, тобто безпосереднього середовища особи [9, с. 362].

Аналізуючи основні поняття, які входять до сфери захисту ст. 8 Конвенції, слід зазначити, що, по-перше, поняття «сімейне життя» найбільш детально розкрито в справі «Marckx v. Belgium» ЄСПЛ і означає зв'язки між членами родини, наприклад між батьком, матір'ю і дітьми, а також між дідусем, бабусею та онуками, причому, відповідно до практики Суду, не існує різниці між «оформленою за законом» і «не оформленою за законом» родиною [10]. «Повага» до сімейного життя покладає на державу зобов'язання сприяти нормальному розвитку таких зв'язків. По-друге, дефініцію поняття «житло» можна побачити в рішенні у справі «Buckley v. UK», де Суд зазначив, що житло - це резиденція, яка облаштована відповідно до чинного законодавства, та визнав, що захистом ст. 8 Конвенції охоплюється навіть циганська кибитка (шатро). Окрім цього, гарантії ст. 8 Конвенції поширюються також на офіси (адвокатів, нотаріусів та ін.) та інші володіння особи [11]. По-третє, поняття права на таємницю кореспонденції було продемонстровано в рішеннях у справах «KlassandOthers v. Germany», і воно означає право на комунікацію з іншими людьми, що є не підцензурними і не перериваються. Однак дія цього права перестає існувати, як тільки лист досяг адресата. Поняття «кореспонденція» включає листи і телефонні комунікації. Захист стосується засобів комунікацій, а не їхнього змісту (яке звичайно належить до компетенції ст. 10 Конвенції) [12].

Доцільно зазначити, що найбільш широким терміном у такому аспекті $є$ поняття «право на приватність», на яке було вказано в багатьох рішеннях ЄСПЛ. До цього поняття входить багато складників, а саме: фізична та психологічна цілісність особи («Pretty v. theUnitedKingdom») [13], численні аспекти фізичної та соціальної ідентичності особи («Mikuli v. Croatia») [14] гендерна ідентифікація, ім'я, сексуальна орієнтація та статеве життя потрапляють у сферу, що також захищаються ст. $8 \mathrm{KoH}^{-}$ венції («Bensaid v. theUnited Kingdom» [15], ім'я особи, ï чи його приватне життя може включати інші засоби особистої ідентифікації та зв'язку з сім'єю («Burghartz v. Switzerland») [16], інформація про стан ї̈ здоров’я («Рішення у справі Z v. Finland») [17], особистий розвиток та право починати та розвивати відносини 3 іншими людьми та довколишнім світом («Friedl v. Austria») [18], певні структурні компоненти права на власне зображення («Sciacca v. Italy») [19].

Важливим аспектом дослідження окреслених питань $€$ те, що ЄСПЛ у багатьох своїх рішеннях наголошував на наявності як негативного, так і позитивного обов'язку держави у забезпеченні права на повагу до приватного та сімейного життя. У свою чергу, негативний обов'язок втілений у захисті приватного та сімейного життя, житла та кореспонденції від свавільного втручання з боку держави. Але відповідно до ст. 8 Конвенції держава повинна не просто утримуватися від незаконного втручання, але й створити механізм ефективного захисту приватного життя. Взагалі, такий механізм полягає у вживанні заходів, які мають забезпечити повагу до приватного життя у відносинах між індивідуумами.

Так, у своїх рішеннях Суд не раз зазначав, зокрема, що існує певна межа між негативними та позитивними зобов'язаннями держави. Відповідно до його усталеної практики, визначаючи зобов'язання, необхідно брати до уваги справедливий баланс, який варто встановити між конкуруючими інтересами суспільства та окремого індивіда, а також принцип свободи розсуду держави («PalomoS nchezandothers v. Spain»; «Eweidaandothers v. GreatBritain») [20, 21]. 
У низці рішень Судом було підкреслено, що під поняття «приватного життя» 3 точки зору ст. 8 Конвенції підпадає систематичне спостереження і збір приватної інформації представниками влади, а також подальше збереження такої інформації у вигляді досьє («Rotaru v. Romania», § 44; «Benedik v. Slovenia», § 101; P.G. i J.H. v. the United Kingdom, § 57) [22, 23, 24]. Динамічний розвиток інформаційних технологій призвів до поширення кіберзлочинів, що спричинило потребу встановлення меж приватного життя в онлайн просторі. Судом було зроблено висновок, що під дію ст. 8 Конвенції підпадає інформація, пов'язана 3 конкретними динамічними IР-адресами, котра полегшуе ідентифікацію автора такої діяльності, що, в принципі, становить особисті дані, котрі не можуть бути відкритими для загалу [24].

Для того аби детально проаналізувати всі складники ст. 8 Конвенції та встановити межі між негативними та позитивними зобов'язаннями держави, варто звернутися до спеціальних принципів, які покладені в основу зазначеної статті та детально розкриваються в рішеннях ЄСПЛ, дозволяючи належно тлумачити ст. 8 Конвенції, встановлювати справедливість у судових рішеннях, правильно забезпечувати органічний взаємозв'язок статей Конвенції та наявних юридичних спорів, ефективно захищати права людини тощо.

Так, одним із найважливіших принципів ст. 8 Конвенції, безумовно, є забезпечення балансу конкуруючих інтересів особи та громадськості. Цей принцип було застосовано в рішенні у справі «Hristozovandothers v. Bulgaria», де заявники, що хворіли на рак, скаржились на те, що їм не було надано доступу до недозволеного експериментального медичного препарату. Інтерес заявників було визначено як «певну свободу вибору засобу крайньої необхідності у вигляді невипробуваних ліків, які можуть призвести до ризиків, але такий вибір розглядається заявниками та їхніми лікарями як доречний у їхній ситуації з метою врятування життя». Публічний інтерес, у свою чергу, складався з трьох елементів: захисту пацієнтів від ризиків лікування, неможливості обминання нормативно-правової бази щодо використання недозволених ліків, не поставлення під загрозу подальшої розробки таких ліків через неефективність лікування на початковому етапі. Питання політики у сфері охорони здоров’я входить до сфери розсуду Договірних Держав, проте наразі немає компромісу щодо врегулювання цього питання. Тому Суд зробив висновок, що досягнута у національному законодавстві рівновага, неза- лежно від того, чи могла бути ця рівновага справедливішою, не вийшла за межі наданої Державі широкої свободи розсуду [25].

3 огляду на те, що доволі багато питань наразі входять до прав держави на розсуд, практика ЄСПЛ також не раз вказувала на важливість цього принципу під час тлумачення ст. 8 Конвенції. Однією 3 найбільш показових справ з приводу даного питання $€$ рішення «Marckx v. Belgium», де у параграфі 29 було вказано, що Державам має бути надано дозвіл на зміну свого ставлення до зазначених подій, коли вони вважають це необхідністю, а також своїми заходами та розумними способами, оскільки державам повинні бути надані певні межі вільного розсуду. Оскільки використання курсу ЕКЗ (Екстракорпоральне запліднення) пов'язане з делікатними моральними і етичними проблемами на тлі швидкого розвитку медицини і науки й оскільки поставлені в справі питання пов'язані зі сферами, в яких серед держав - членів Ради Свропи немає загального підходу, Суд вважає, що свобода розсуду, яка надається державі-відповідачу, повинна бути широка [10].

Рішення у делікатних справах не може бути винесено на основі механістичного спрощення - серед європейських країн немає консенсусу, тому держава має широкі рамки розсуду; свобода розсуду стосується і законодавчого акта; свобода розсуду поширюється і на ті норми, які він встановлює 3 метою досягнення балансу конкуруючих публічних і приватних інтересів. Зрозуміло, державам повинні бути надані широкі рамки розсуду, коли йдеться про прийняття законодавства, яке регулює використання ЕКЗ

Однак ця свобода розсуду не повинна заважати Суду здійснювати свої контрольні повноваження, особливо у звязку з питанням про те, чи був на внутрішньодержавному рівні досягнутий баланс усіх конкуруючих інтересів. Суд не повинен використовувати принцип свободи розсуду як чисто прагматичний замінник продуманого підходу до проблеми визначення належного обсягу перевірки Судом внутрішньодержавних норм.

Також на існування цього принципу Суд вказав у своєму рішенні «Sabanchiyevaandothers v. Russia», де визнав, що абсолютна заборона повернення тіл ймовірних терористів не забезпечує належного балансу між державою та правами членів сім’ї загиблого за ст. 8 Конвенції. Як підсумок, взявши до уваги автоматичну природу заходу 3 втручання у право заявників, не дотримання принципу пропорційності органів влади, Суд вважає, що захід, про який ідеться, порушує справедливу рівновагу 
між правом заявників на захист приватного та сімейного життя, з одного боку, та законні цілі захисту громадської безпеки, запобігання заворушенням та захисту прав та свобод інших осіб, з іншого боку [26].

Доцільно також буде наголосити на наявності ще одного важливого принципу, а саме необхідності застосування заходів щодо захисту прав, що охороняються ст. 8 Конвенції в демократичному суспільстві. Його було застосовано в рішенні у справі «RomanZakharov v. Russia». Нерідко такий принцип вживається у справах про застосування заходів негласного спостереження. У цьому випадку важливим є те, що необхідно відповісти на питання: чи задовольняє застосування таких заходів вимоги «необхідності в демократичному суспільстві», наприклад, чи можна досягти поставлених цілей шляхом вжиття менш обмежувальних засобів. Законність втручання до приватного життя в такому аспекті пов'язана з тим, чи була проведена попередня перевірка на необхідність такого втручання. У такому сенсі «якість закону» означає, що законодавство держави повинно бути не лише передбачуваним та доступним у застосуванні, але й гарантувати, що заходи, які порушують приватне життя, мають застосовуватись лише, якщо це «необхідно в демократичному суспільстві» [27].

Сторони у цій справі не заперечували перехоплення мобільних повідомлень у межах національного законодавства Російської Федерації, адже такі заходи є дозволеними, оскільки мають законну мету захисту національної безпеки, економічного добробуту та попередження злочинності в державі [27]. Але ССПЛ все ж повинен встановити, чи $€$ російське законодавство доступним, чи відповідає вимогам передбачуваності та чи є такі заходи в цій ситуації необхідними в демократичному суспільстві.

Так, зокрема, Суд вказує на те, що у російському законодавстві зазначено, що дозвіл на перехоплення може бути виданий не лише щодо підозрюваного або обвинувачуваного, а й щодо особи, яка може мати в розпорядженні інформацію про злочин або іншу інформацію, що стосується кримінальної справи. При цьому в законодавстві відсутні уточнення щодо того, як поняття «особа, яка може мати інформацію про кримінальний злочин» і «особа, яка може мати в розпорядженні інформацію, що стосується кримінальної справи» слід застосовувати на практиці. Закон про оперативно-розшукову діяльність передбачає, що телефонні й інші повідомлення можуть бути перехоплені після отримання інформації про події або діяльність, що становить загрозу для національної, військової, економічної або екологічної безпеки Російської Федерації. При цьому, як констатує ЄСПЛ, російським законодавством не визначено, які саме події або діяльність можна розглядати як такі, що становлять загрозу зазначеним видам безпеки [27].

Отже, закон повинен визначати межі будьякого розсуду, наданого уповноваженому органу, і спосіб його здійснення з достатньою ясністю, враховуючи законні цілі заходу, про який ідеться, щоб надати особі належний захист від свавільного втручання.

Такий же підхід простежується у справі «HashmanandHarrup v. TheUnitedKingdom», де вказується, що жодну норму не можна вважати законом, якщо вона не досить чітко сформульована, що давало б особі можливість керуватися цією нормою виключно в своїх інтересах, які не завжди переслідують законні цілі. Ступінь чіткості, яку мають забезпечувати формулювання національних законів і яка в жодному разі не може охопити всі непередбачувані обставини, значною мірою залежить від змісту певного документа, сфери, на яку поширюється закон, а також від кількості та статусу тих, кому він адресований (п. 31) [28].

Варто зазначити, що ця справа $€$ особливою, адже в ній зазначено втручання у свободу вираження поглядів, але не у вигляді покарання за заборонену поведінку, а у вигляді розпорядження про те щоб заявники в майбутньому не порушували громадського спокою та не вдавалися до «contrabonosmores» - поведінки, яка відповідно до британського законодавства означає дії, які суспільство вважає скоріше поганими, аніж добрими. У цій справі розпорядження про недопущення такої поведінки викладено не досить чітко і загальними словами, без конкретики. Адже словосполучення «добре поводитись» є дуже неточним і для особи, на яку було покладено зобов'язання, і не може бути керівництвом для того, щоб розуміти, які дії можуть нести за собою порушення такого розпорядження [28].

Іншим важливим принципом, що покладений в основу ст. 8 Конвенції, є сприяння законній меті. Цей принцип знайшов своє відображення в рішенні «S.A.S. v. France». Так, відповідно до обставин справи, заявниця, яка є правовірною мусульманкою, вказувала, що носить паранджу і нікаб відповідно до своїх культурно-релігійних та особистих переконань. Потреба у судовій справі виникла внаслідок заборони французьким законом від 11 жовтня 2020 року носити одяг, що відповідає їі релігійним переконанням. Уряд Франції стверджував, що таке 
втручання переслідує 2 легітимні цілі: забезпечення «громадської безпеки» та «поваги до мінімального набору цінностей відкритого і демократичного суспільства». Суд визнав, що, встановлюючи зазначену заборону, законодавчий орган намагався вирішити питання «громадської безпеки» у значенні других пунктів статей 8 та 9 Конвенції, та зазначив, що держава може вважати дуже необхідним наявність можливості ідентифікації фізичних осіб з метою запобігання небезпеці спричинення шкоди людям і майну та протидіі шахрайству з персональними даними [29].

Уряд зазначив, що носіння паранджі деякими жінками шокує більшість населення Франції, оскільки порушує загальноприйнятий у Франції принцип гендерної рівності. Суд, аналізуючи це твердження, вказав, що забезпечення поваги до людської гідності не може бути легітимною підставою для повної заборони на носіння паранджі в громадських місцях. Цей одяг міг викликати подив у населення, але він є частиною культурної ідентичності, що сприяє утвердженню плюралізму, притаманного демократії. Але, беручи також до уваги принцип необхідності «дотримання мінімальних норм життя в суспільстві», на яку вказував уряд, Суд зазначив, що це твердження може мати значення для легітимної мети «захисту прав і свобод інших осіб». Обличчя відіграє важливу роль у соціальній взаємодії, а тому Суд погодився $з$ тим, що бар'єр, спрямований проти інших осіб, який створюється одягом, що приховує обличчя, сприймається державою-відповідачем як порушення права інших осіб жити у просторі соціалізації, в якому жити разом легше [29]. Таким чином, можна побачити, що сприяння легітимній меті є важливим принципом, що покладено в основу ст. 8 Конвенції.

Не можна також проігнорувати принцип відповідності між соціальною реальністю та законом, який було висвітлено у справі $\ll \mathrm{H} \mathrm{m} l$ inen v. Finland». Основним твердженням правової позиції Суду у цьому рішенні $€$ таке: «Певні чинники мають бути визнані доречними в оцінці змісту цих позитивних зобов'язань держав. Вони стосуються важливості інтересів, що стоять на кону, і того, чи розглядаються «фундаментальні цінності» чи «суттєві аспекти» приватного життя або впливу на заявника розбіжностей між соціальною реальністю і законом», тобто, визначаючи обсяг позитивних зобов'язань держави, варто брати до уваги стан розвитку суспільства в державі та стан розвитку законодавства і правових норм, що захищають право на приватне життя [30].

Останнім, але не менш важливим принципом, що покладений в основу ст. 8 Конвенції,
$€$ чіткість обсягу дискреційних повноважень органів державної влади. Цей принцип регламентуе визначеність законної межі втручання держави в приватне життя громадян. Принцип знайшов свої втілення в багатьох рішеннях ССПЛ. Так, наприклад, у рішенні у справі «Ta k nandother v. Turkey» зазначено, що процес прийняття рішень, який веде до заходів втручання, повинен бути справедливим та забезпечувати належну повагу до інтересів особи, як це передбачено ст. 8 Конвенції [31].

Також показовою справою 3 цього питання $\epsilon$ «Giacomelli v. Italy», де вказано, що треба вдаватися лише до розумних й адекватних заходів для забезпечення прав, передбачених ст. 8 Конвенції. Держава має шукати баланс між інтересами індивідуума та суспільства в цілому у разі втручання в його приватне життя [32].

Такий же підхід можна простежити у справі «Piechowicz v. Poland», де в рішенні було зазначено, що обсяг та спосіб здійснення відповідного рішення органом державної влади має бути зазначено у внутрішньому законодавстві, щоб забезпечити особам мінімальний рівень захисту, якого вимагає принцип верховенства права у демократичному суспільстві [33].

\section{Висновки}

Отже, на підставі викладеного зазначимо, що практика Європейського суду 3 прав людини є динамічним джерелом права і сприяє формуванню єдності судової практики у контексті захисту прав, свобод та інтересів особи. Ст. 8 Конвенції не тільки закріплює одне 3 фундаментальних прав особи та захищає від порушення його державою, а й створює та розвиває найбільш ефективне поле для захисту прав, яке би превентивно враховувало наявну практику Суду.

У своїй практиці ЄСПЛ виробив одностайність у тлумаченні таких найважливіших складників змісту ст. 8 Конвенції, як «житло», «кореспонденція», «приватне життя», «сімейне життя», що є неабияким здобутком не тільки для застосування іï положень Судом, а й для правозастосування Конвенційних засад Договірними Державами. Нині, враховуючи відповідну практику та правові позиції Суду, більшість країн може активно впроваджувати у національне законодавство нові засади, поняття, критерії визначення правопорушень, способи захисту та відновлення порушених прав, встановлювати позитивні та негативні зобов'язання держави перед особами та релевантно застосовувати практику ССПЛ, вдосконалюючи свою правову систему. 


\section{Список використаних джерел:}

1. Платон Держава / за ред. Д. Коваля. Київ : Основи, 2000. 355 с

2. Уоррен С., Брандейс Л. Право на приватність : наукова стаття. Право США. 2013. № 1-2. c. 132-153. URL: http://nbuv.gov.ua/ UJRN/prccha_2013_1-2_11 (дата звернення: 12.04.2021).

3. Загальна декларація прав людини: Резолюція Генеральної Асамблеї ООН від 10 грудня 1948 p. № 217 A (III). URL: http://zakon.rada. gov.ua/laws/show/995_015 (дата звернення: 24.04.2021).

4. Міжнародний пакт про економічні, соціальні і культурні права: Резолюція Генеральної Асамблеї від 16 грудня 1966 р. № 2200 А (XXI). URL: http://zakon2.rada.gov.ua/laws/ show/995_042 (дата звернення: 24.04.2021).

5. Конвенція про захист прав людини i основоположних свобод: Рада Європи. URL: http://zakon2.rada.gov.ua/laws/show/995 004 (дата звернення: 24.04.2021).

6. Мішуровська С. Т. Міжнародно-правовий захист права на приватне життя (сучасна практика) : автореф. дис. ... канд. юрид. наук: 12.00.11. Харків, 2011. 21 с

7. Серьогін В. О. Право на недоторканність приватного життя у конституційно-правовій теорії та практиці : монографія. Харків : ФІНН, 2010. 608 с.

8. Панкевич О. Право на приватність: царина незалежності особи. Науковий вісник ЛДуВС. 2017. № 2. C. 51-62. URL: https://www.lvduvs.edu.ua/ documents_pdf/visnyky/nvsy/02_2017/8.pdf

9. Шевчук С. Судовий захист прав людини: Практика Європейського Суду з прав людини у контексті західної правової традиції : навчальний посібник. 2-ге вид., переробл. і випр., Київ, 2007. 848 с.

10. Case of MARCKX v. BELGIUM Application № 6833/74. URL: http://hudoc.echr.coe.int/ fre? $\mathrm{i}=001-57534$ (дата звернення: 24.04.2021)

11. Case of BUCKLEY v. THE UNITED KINGDOM, Application № 20348/92. URL: http:// hudoc.echr.coe.int/eng?i=001-58076 (дата звернення: 24.04.2021)

12. Case of KLASS AND OTHERS v. GERMANY, Application № 5029/71. URL http://hudoc.echr.coe.int/fre?i=001-57510 （дата звернення: 24.04.2021)

13. Chamber judgment in the case of PRETTY v. THE UNITED KINGDOM, Application № 2346/02. URL: http://hudoc.echr.coe.int/ fre? $\mathrm{i}=003-542432-544154$ (дата звернення: 24.04.2021).

14. Judgment in the case of MIKULI v. CROATIA, Application № 53176/99. URL: https://hudoc.echr.coe.int/app/conversion/pdf $/$ ?library $=$ ECHR\&id $=003-489754-491011 \&$ file name=003-489754-491011.pdf (дата звернення: 24.04.2021)

15. Case of BENSAID v. UNITED KINGDOM, Application № 44599/98. URL: https://hudoc.echr.coe.int/app/conversion/pdf/?1 ibrary $=$ ECHR\&id $=002-5771 \&$ filename $=002-5771$. pdf\&TID=ihgdqbxnfi (дата звернення: 24.04.2021)

16. Case of BURGHARTZ v. SWITZERLAND Application № 16213/90. URL: http://hudoc echr.coe.int/eng?i=001-57865 (дата звернення: 24.04.2021).

17. Case of $\mathrm{Z}$ v. FINLAND, Application № 22009/93. URL: https://www.refworld.org/ cases,ECHR,3ae6b71d0.html (дата звернення: 24.04.2021).

18. Case of FRIEDL V AUSTRIA, Application № 15225/89. URL: https://www.bailii.org/eu/ cases/ECHR/1995/1.html (дата звернення: 24.04.2021)

19. Case of SCIACCA v. ITALY, Application № 50774/99. URL: https://hudoc.echr.coe.int/app/ conversion/pdf/?library $=$ ECHR\&id $=003-1235019$ 1285595\&filename=003-1235019-1285595.pdf (дата звернення: 24.04.2021)

20. Case of PALOMO SNCHEZ AND OTHERS v. SPAIN, Applications № 28955/06, 28957/06, 28959/06, 28964/06. URL: https://www. legal-tools.org/doc/30d643/pdf/ (дата звернення: 24.04.2021).

21. Case of ROTATU v. ROMANIA, Applications № 28341/95. URL: https://hudoc.echr. coe.int/eng\#\{\%22itemid\%22:[\%22001-58586\%22]\} (дата звернення: 24.04.2021).

22. Case of BENEDIK v. SLOVENIA, Applications № 62357/14. URL: https://hudoc.echr. coe.int/fre\#\{\%22itemid\%22:[\%22001-182455\%22]\} (дата звернення: 24.04.2021).

23. Case of P.G. AND J.H. v. THE UNITED KINGDOM, Applications № 44787/98. URL: https://hudoc.echr.coe.int/eng\#\{\%22 ite mid\%22:[\%22001-59665\%22]\} (дата звернення: 24.04.2021).

24. Case of EWEIDA AND OTHERS v. THE UNITED KINGDOM, Applications № 48420/10, 59842/10, 51671/10, 36516/10. URL: http://hudoc. echr.coe.int/fre?i=001-115881 (дата звернення: 24.04.2021).

25. Case of HRISTOZOV AND OTHERS v. BULGARIA, Applications № 47039/11, 358/12. URL: http://hudoc.echr.coe.int/fre?i=001-114492 (дата звернення: 24.04.2021)

26. Case of SABANCHIYEVA AND OTHERS v. RUSSIA, Application № 38450/05. URL: http:/ hudoc.echr.coe.int/eng?i=001-120070 (дата звернення: 24.04.2021).

27. Case of ROMAN ZAKHAROV V. RUSSIA, Application № 47143/06. URL: http:// hudoc.echr.coe.int/app/conversion/docx/ CHR\&id=001-159324\&filename $=$ CASE $\% 20$ OF\%20ROMAN\%20ZAKHAROV\%20v.\%20 RUSSIA.pdf (дата звернення: 24.04.2021).

28. Execution of the judgment of the European Court of Human Rights Hashman and Harrup against the United Kingdom, Applications № 47039/11, 358/12. URL: http://hudoc.echr. coe.int/ENG?i=001-106995 (дата звернення: 24.04.2021) 
29. Case of S.A.S. v. FRANCE, Application № 43835/11. URL: https://hudoc.echr.coe.int/app/ conversion/pdf/?library $=$ ECHR\&id $=001-145466 \&$ filename $=001-145466$.pdf \&TID=uexpxlonsk $\quad$ (дата звернення: 24.04.2021)

30. Case of H M LINEN v. FINLAND, Application № 37359/09. URL: http://hudoc. echr.coe.int/fre?i=001-145768 (дата звернення: 24.04.2021)

31. Case of TAKIN AND OTHERS v. TURKEY, Application № 46117/99. URL http://hudoc.echr.coe.int/eng?i=001-67401 （дата звернення: 24.04.2021).

32. Chamber judgment in the case of GIACOMELLI v. ITALY, Application № 59909/00. URL: https://www.eufje.org/images/docConf/ buc2016/CASE\%20OF\%20GIACOMELLI\%20 v.\%20ITALY.pdf (дата звернення: 24.04.2021).

33. Case of PIECHOWICZ v. POLAND, Application № 20071/07. URL: http://hudoc. echr.coe.int/eng?i=001-110499 (дата звернення: 24.04.2021).

Oleksandra Babaeva, Oleksandra Iordanova, Krystyna Lahutina. The right to interference in private and family life: practice of the European Court of Human Rights

The article is devoted to the study of the right to non-interference in the private and family life of a person, which is enshrined in Article 8 of the Convention for the Protection of Human Rights and Fundamental Freedoms of 1950. Issues related to the historical formation of the concept of privacy are analyzed, in particular, Plato's work "State", a scientific article by S. Warren and L. Brandeis, which initiated the development of the human right to privacy, scientific articles by domestic scholars, as well as international legal acts in which this concept was officially enshrined. Attention is paid to different approaches to the consideration of the right to privacy, attention is paid to the analysis of the four components of the right to non-interference in private and family life, namely: private life, family life, housing and correspondence. On the basis of scientific works of specialists in the field of law, the emphasis is on the fact that the right to respect for private life can include informational, physical, nominative and spatial components.

Based on the analysis of the decisions of the European Court of Human Rights (hereinafter - the ECtHR, the European Court of Justice, the Court), it was found that the concept of "family life" covers relationships between family members, emphasizing that there is no difference between the registration and nonregistration of kinship by law, the concept of "housing" in the sense of the European Court was also defined, the components of the term "private life" were revealed.

It is stated that the concept of "private life" includes such aspects as physical and psychological integrity of a person, aspects of physical and social identity of a person, gender identification, name, sexual orientation and sexual life, systematic observation and collection of private information by representatives authorities, as well as the further preservation of such information in the form of a dossier.

Careful attention is paid to the analysis of the negative and positive duty of the state in ensuring the right to respect for private and family life. It was emphasized that in determining the obligations it is necessary to take into account a fair balance, which should be established between the competing interests of society and the individual, the principle of discretion of the state to legislation and norms relating to achieving a balance of competing public and private interests. and the principle of the need to apply measures to protect the rights protected by Article 8 of the 1950 Convention for the Protection of Human Rights and Fundamental Freedoms.

Key words: privacy, ECHR, privacy, protection of family life, European Court of Human Rights. 